\title{
KLASIFIKASI KELUHAN PELANGGAN BERDASARKAN TINGKAT PENANGANAN PADA PERUSAHAAN LAYANAN INTERNET MENGGUNAKAN ROCCHIO CLASSIFIER
}

\author{
Wildan Suharso ${ }^{1}$, Hardianto Wibowo ${ }^{2}$ \\ Teknik Informatika, Teknik, Universitas Muhammadiyah Malang \\ Jalan Raya Tlogomas 246 Malang \\ E-Mail: wsuharso@umm.ac.id
}

\begin{abstract}
Abstrak
Banyak penelitian yang dilakukan untuk meneliti perusahaan layanan internet di Indonesia mulai dari penggunaan database, customer churn hingga penyelarasan tujuan teknologi informasi. Penelitian yang dilakukan oleh Suharso tahun 2013 menyatakan bahwa pelanggan tidak akan berpindah pada perusahaan pesaing jika pengguna merasa nyaman dengan layanan yang diberikan, namun permasalahan pelanggan tidak hanya disebabkan oleh layanan, aplikasi yang mendukung turut mendukung proses bisnis yang dilakukan seperti yang telah dijelaskan oleh Suharso pada tahun 2016. Salah satu aplikasi yang harus dibangun pada ISP adalah aplikasi yang memudahkan pegawai perusahaan layanan internet atau ISP dalam menyelesaikan keluhan pelanggan karena ditemukan keragaman penyelesaian permasalahan sehingga menyebabkan kurang standarnya waktu penyelesaian. Pendekatan text mining dilakukan untuk meminimalisir permasalahan dengan menggunakan rocchio classifier yang terdiri dari beberapa tahapan antara lain studi pustaka, pengumpulan data, preprocessing, features selection, rocchio classifier, dan analisis hasil. Hasil yang diperoleh antara lain waktu rata rata proses parsing adalah 0,0333 detik, rata-rata proses klasifikasi adalah 0,0905 detik, dan ratarata keseluruhan proses adalah 0,1238 detik, selain secara fungsional aplikasi dapat membantu customer service dalam menentukan tingkat penanganan masalah.
\end{abstract}

Kata Kunci:klasifikasi, rocchio, isp, perusahaan layanan internet, text mining

\section{PENDAHULUAN}

Pengguna Internet di seluruh dunia selalu mengalami peningkatan, pada tahun 2015 pengguna internet mencapai 3,2 juta Miliar pengguna (Sanou, 2015). Peningkatan ini dipengaruhi oleh kecenderungan dalam menggunakan internet (Brown, 2015). Indonesia merupakan negara yang memiliki peningkatan jumlah pengguna internet yang cukup tinggi sehingga perlu dilakukan penelitian terkait internet, kecenderungan, ataupun teknologi yang menyebabkan perubahan atau efek lain pada penggunaan internet.

Peningkatan pengguna internet turut mendorong peningkatan perusahaan yang menyediakan jasa layanan internet yang biasa disebut dengan Internet Service Provider (ISP). Pada awal tahun 2000-an hingga 2013 tercatat banyak izin yang dikeluarkan untuk pendirian ISP baik berskala kecil atau skala Nasional. Semakin beragam ISP maka semakin banyak pilihan yang diberikan kepada pelanggan atau pengguna internet sehingga muncul kecenderungan untuk berpindah-pindah dari satu perusahaan ke perusahaan penyedia layanan internet yang lain.

Penelitian sebelumnya yang telah dilakukan adalah banyak pelanggan internet yang berpindah karena beberapa hal antara lain jenis layanan, bonus, atau keluhan pelanggan (Suharso, 2013), penyelarasan tujuan bisnis dan tujuan teknologi informasi perlu dilakukan untuk menganalisis permasalahan dari sudut pandang yang berbeda sehingga diperoleh portofolio aplikasi yang diperlukan pada perusahaan layanan internet
(Suharso, 2016). Salah satu permasalahan yang ditemukan pada perusahaan layanan internet adalah keluhan pelanggan dan penanganan yang beragam membuat pelanggan berfikir atau cenderung untuk berpindah pada perusahaan pesaing.

Penanganan keluhan pelanggan pada ISP dilakukan dengan memisah permasalahan pada beberapa bagian, pada perusahaan yang dijadikan studi kasus dibagi ke dalam 3 tingkat penanganan, yaitu penanganan keluhan tingkat pertama yang diselesaikan langsung dari Customer Support atau Customer Service, keluhan pelanggan tingkat kedua yang diselesaikan oleh teknisi dengan mengecek langsung ke lokasi permasalahan, dan keluhan pelanggan tingkat ketiga yang diselesaikan oleh NOC Staff atau Kepala Divisi Jaringan. Walaupun telah terdapat pembagian penyelesaian permasalahan namun waktu penyelesaian tidak dapat dipastikan karena permasalahan beragam bahkan pada studi kasus ditemukan permasalahan yang terselesaikan lebih dari 24 jam.

Permasalahan keluhan pelanggan yang tidak dapat diselesaikan secara cepat dapat mempengaruhi keputusan pelanggan untuk loyal pada perusahaan. Permasalahan yang tidak terselesaikan atau yang tidak diselesaikan secara cepat disebabkan oleh beberapa hal antara lain ketersediaan waktu teknisi, ketersediaan hardware pengganti, prosedur pengusulan alat pengganti, dan permasalahan waktu tunggu customer service dalam memberikan penjelasan terkait permasalahan.

Aplikasi keluhan pelanggan diharapkan mampu membantu customer service dan teknisi dalam 
menyelesaikan permasalahan. Penelitian terkait aplikasi keluhan pelanggan pernah dilakukan pada tahun 2015 yang membahas mengenai perancangan sistem komplain pelanggan untuk mengetahui tingkat kepuasan pelanggan pada ISP (Haryono, 2015). Pada pengamatan yang dilakukan pada perusahaan yang dijadikan studi kasus ditemukan bahwa terdapat aplikasi keluhan pelanggan namun tidak berjalan maksimal, daftar keluhan pelanggan hanya dicatat pada log book atau buku catatan harian komplain. Catatann keluhan disampaikan pada teknisi secara langsung atau menggunakan telepon ataupun email (surat elektronik). Setelah permasalahan terselesaikan maka customer service menuliskan kembali pada log book.

Waktu tunggu yang dihasilkan dari proses penyelesaian keluhan pelanggan dari sejak pelaporan hingga penulisan penyelesaian masalah cukup beragam, sehingga berdasarkan hal tersebut diperlukan aplikasi yang dapat membantu customer service dalam penyelesaian permasalahan keluhan. Fitur utama yang dibutuhkan adalah klasifikasi keluhan berdasarkan tingkat penanganan sehingga customer service dapat menjelaskan secara cepat kondisi permasalahan yang dihadapi oleh pelanggan.

Keluhan pelanggan pada dasarnya berupa teks karena sangat jarang keluhan menggunakan media lain, pelanggan sering menggunakan telepon saat mengadukan permasalahan internet kepada perusahaan penyedia layanan karena lebih cepat dan mampu menjelaskan informasi secara tepat. Aplikasi yang dapat membantu customer service sangat diutamakan dalam permasalahan ini sehingga pelanggan dapat mendapat jawaban secara singkat terkait tingkat penanganan.

Customer service dapat menjelaskan kepada pelanggan pada tingkat mana permasalahan tersebut akan terselesaikan dan customer service mendelegasikan kepada pegawai yang berkepentingan. Klasifikasi melalui aplikasi akan membantu dikarenakan data permasalahan sebelumnya telah disimpan pada database sehingga permasalahan baru dengan kasus yang hampir sama atau sama akan lebih cepat terselesaikan. Salah satu metode yang digunakan dalam klasifikasi adalah rocchio yang merepresentasikan dokumen ke dalam vektor kemudian mengukur bobot dan menghitung kedekatan setiap prototipe vektor dengan vektor data tes. Penulis telah melakukan penelitian terkait teks mining dan metode rocchio pada tahun 2008, yaitu klasifikasi berita berbahasa indonesia menggunakan metode rocchio. Metode ini membagi data menjadi dua, yaitu data training dan data tes. Data training merupakan kumpulan berita yang telah terklasifikasi dan data tes yang merupakan data tunggal data yang belum diklasifikasi.

Data yang digunakan pada kasus keluhan pelanggan pada perusahaan layanan internet merupakan data yang berjenis sama yaitu teks, namun pada konteks yang berbeda. Jika pada penelitian sebelumnya yang dilakukan adalah pada berita online namun pada penelitian ini digunakan keluhan pelanggan yang sebelumnya telah disimpan pada perusahaan layanan internet sehingga perlu penyesuaian. Tahapan yang digunakan pada penelitian ini meliputi preprocessing, features selection, rocchio classifier, dan analisis hasil.

\section{METODOLOGI PENELITIAN}

Pada penelitian ini digunakan pendekatan teks mining untuk menyelesaikan permasalahan, yaitu menggunakan rocchio classifier. Secara umum metodologi penelitian meliputi studi pustaka, pengumpulan data, preprocessing, features selection, rocchio classifier, dan analisis hasil yang ditunjukkan pada gambar 1 .

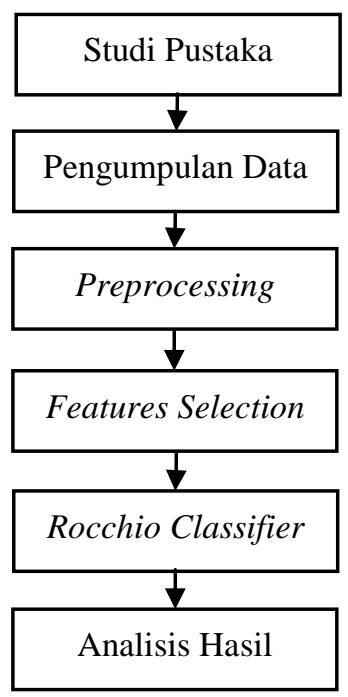

Gambar 1. Metodologi Penelitian

Pada gambar 1 ditunjukkan tahapan penelitian yang digunakan pada semua data, meliputi data training dan data tes. Tahapan preprocessing dan features selcetion dilakukan secara terpisah pada data training dan data tes, namun pada tahapan rocchio classifier kedua jenis data tersebut digunakan secara bersama-sama. Penelitian ini menggunakan PHP dan MySQL untuk menyelesaikan

\subsection{Studi Pustaka}

Terdapat beberapa penelitian yang digunakan antara lain penelitian yang melakukan klasifikasi dokumen yang menunjukkan akurasi diatas $70 \%$ yang menggunakan rocchio classifier (Lumbanraja, 2013), Penelitian mengenai penelusuran katalog perpustakaan dengan mengimplementasikan rocchio relevance feedback (Yugianus, 2013), penelitian terkait perusahaan layanan internet (Suharso, 2013), penelitian terkait rocchio classifier yang menunjukkan bahwa rocchio merupakan algoritma dengan komputasi rendah namun memberikan nilai presisi yang tinggi (Tarrago, 2014), penelitian terkait sistem informasi keluhan pelanggan (Fajarita, 2015), dan penelitian terkait frequently asked questions otomatis untuk keluhan pelanggan (Saptono, 2015). 


\subsection{Pengumpulan Data}

Tahapan ini dilakukan untuk mengumpulkan data pada studi kasus baik berupa dokumen, data yang tersimpan, ataupun data hasil observasi dan wawancara. Pada penelitian ini digunakan 3 perusahaan layanan internet berskala nasional di wilayah Jawa Timur terutama yang berkedudukan di Kota Malang.

\subsection{Preprocessing}

Pada tahapan ini dilakukan persiapan data untuk disesuaikan dengan program yang akan dibangun, perprocessing tidak hanya dilakukan untuk mendapatkan plain text saja, namun juga dilakukan penyalinan dokumen, pengetikan ulang dokumen, dan memasukkan ke dalam database yang sesuai.

\section{$2.4 \quad$ Features Selection}

Pada tahapan ini dilakukan proses features selection yang bertujuan untuk memilih fitur-fitur yang hanya digunakan pada rocchio classifier. Pada tahap ini dilakukan penghapusan kata yang tidak memiliki makna atau disebut dengan stopword, pembuatan kamus stopword untuk memudahkan seleksi fitur. Stemming juga dilakukan pada tahapan ini untuk mendapatkan fitur yang optimal dan mengurangi kata dengan makna dasar yang sama karena adanya imbuhan. Pada tahap ini juga digunakan kamus untuk kata yang tidak perlu untuk dilakukan stemming.

\subsection{Rocchio Classifier}

Metode rocchio merepresentasikan seluruh kata yang telah melewati tahapan features selection sebagai dimensi yang salin terkait, secara sederhana kalimat dituliskan ke dalam sekumpulan kata yang telah melewati tahap sebelumnya yang direpresentasikan dalam sebuah titik dalam sebuah dimensi n. Rocchio classifier dituliskan dalam persamaan 1 .

$$
\mathrm{H}_{\text {TFIDF }}\left(\mathrm{d}^{\prime}\right)=\arg \max \frac{\sum_{\mathrm{k}=1}^{|\mathrm{F}|} \mathrm{c}_{\mathrm{j}}^{(\mathrm{k})} \cdot \mathrm{d}^{\prime(\mathrm{k})}}{\sqrt{\sum_{\mathrm{k}=1}^{|\mathrm{F}|}\left(\mathrm{c}_{\mathrm{j}}^{(\mathrm{k})}\right)^{2}} \sqrt{\sum_{\mathrm{k}=1}^{|\mathrm{F}|}\left(\mathrm{d}^{\prime}(\mathrm{k})\right)^{2}}}
$$

Pada persamaan 1 ditunjukkan bahwa nilai data tes akan bernilai maksimal dengan kategori tertentu jika ditemukan nilai terbesar pada salah satu kategori, dimana d' menunjukkan data tes, $\mathrm{k}$ menunjukkan angka yang terus bertambah mengindikasikan jumlah kata dalam dokumen, $c_{j}$ menunjukkan kategori. Sedangkan TFIDF menunjukkan bobot kata dalam setiap dokumen biasa disebut denga pembobotan TFIDF (Term Frequency Inverse Document Frequency).

\subsection{Analisis Hasil}

Pada tahap ini dilakukan pengujian hingga analisis terhadap hasil yang diperoleh, dilakukan pula pengkajian aplikasi yang dihasilkan terhadap permasalahan penelitian.

\section{HASIL DAN PEMBAHASAN}

\subsection{Hasil}

Hasil yang diperoleh pada penelitian ini adalah aplikasi yang menerapkan rocchio classifier pada keluhan pelanggan. Secara umum aplikasi dapat membantu proses penanganan keluhan pelanggan berdasarkan tingkat penanganan. Gambar aplikasi ditunjukkan pada gambar 2 .

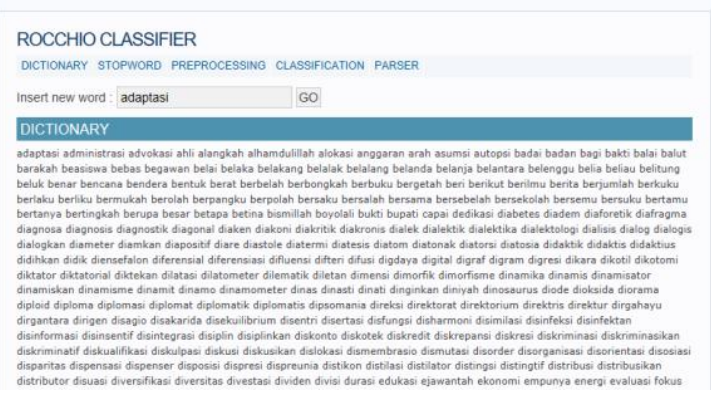

Gambar 2. Tampilan Aplikasi

Pada gambar 2 ditunjukkan hasil dari aplikasi penanganan keluhan pelanggan. Terdiri dari beberapa halaman antara lain dictionary, stopword, preprocessing, classification, dan parser. Halaman dictionary terdiri dari dua bagian, pada field isian untuk menambahkan kata baru, sedangkan pada bagian bawah, atau baris bawah digunakan untuk melihat kata yang ada pada dictionary, penghapusan kata dictionary dapat dilakukan secara langsung dengan mengklik salah satu kata yang ada di dalam daftar dictionary.

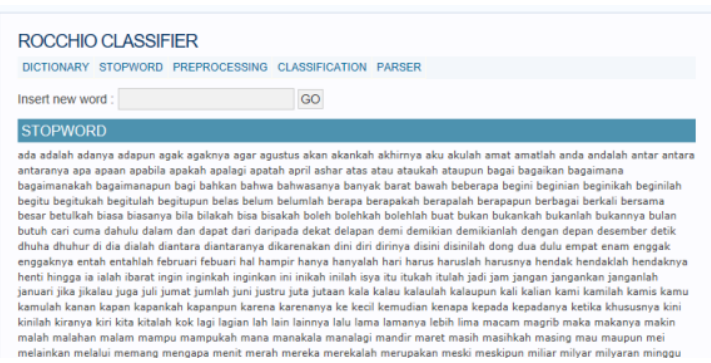

Gambar 3. Halaman Stopword

Pada gambar 3 ditunjukkan halaman stopword yang hampir sama secara fungsi aplikasi dengan halaman dictionary, hanya saja dictionary digunakan untuk kata yang penting dan tidak melewati stemming karena jika dilakukan stemming akan merubah makna, sedangkan stopword adalah deret kata yang secara otomatis dihapus sebelum melewati proses stemming.

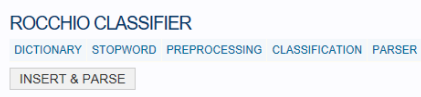

Gambar 4. Halaman Preprocessing

Pada gambar 4 ditunjukkan halaman preprocessing yang hanya terdapat tombol "insert \& 
parse" yang secara otomatis akan melakukan preprocessing pada semua data training berdasarkan folder yang menunjukkan klasifikasi tingkat penanganan. Features selection juga dilakukan kemudian disimpan dalam database.

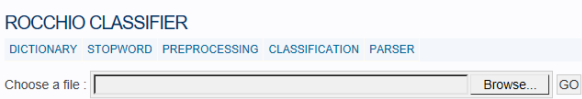

\section{Gambar 5. Halaman Classification}

Pada gambar 5 ditunjukkan halaman Classification yang hanya berisikan tombol browse untuk memilih data tes, data yang dapat digunakan adalah semua file yang bertipe teks. Saat data telah dipilih maka aplikasi akan mengklasifikasikan data tes bersama-sama dengan seluruh data training yang sebelumnya telah dilakukan preprocessing.

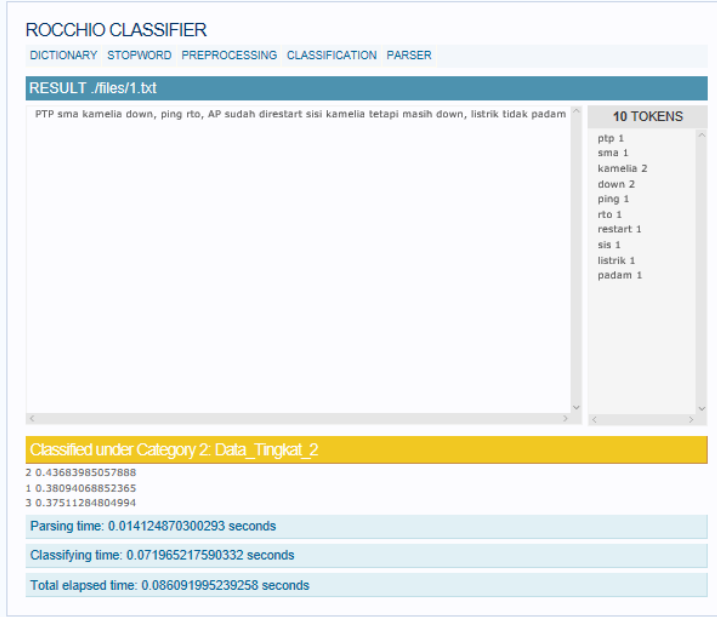

Gambar 6. Hasil Klasifikasi

Pada gambar 6 ditunjukkan hasil dari proses klasifikasi yang ditunjukkan token hasil preprocessing, hasil klasifikasi beserta nilai, waktu melakukan parsing, waktu klasifikasi dan total waktu untuk keseluruhan proses.

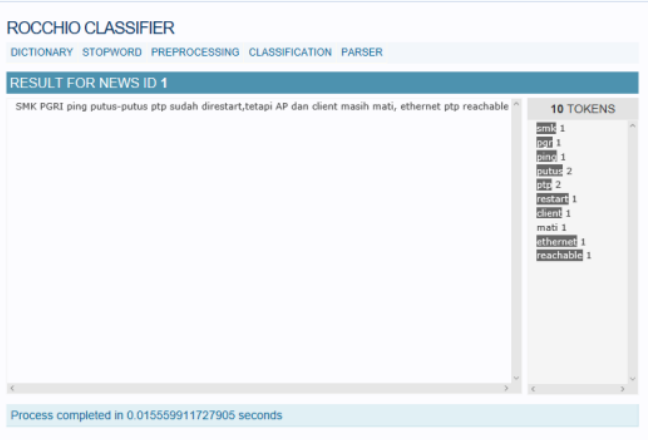

Gambar 7. Hasil Parser

Pada gambar 7 ditunjukkan hasil parser yang merupakan halaman khusus untuk mengecek hasil preprocessing dan stemming pada data training ataupun data tes. Pada halaman parser pula kita dapat mengetahui kata-kata yang digunakan pada klasifikasi.

Hasil yang diperoleh pada contoh klasifikasi yang ditunjukkan pada gambar 6 adalah keluhan pelanggan termasuk dalam kategori 2, yaitu "teknisi" dengan nilai cosinus 0,437 , dengan waktu parsing 0,0141 detik, waktu klasifikasi 0,072 detik, total waktu yang dibutuhkan adalah 0,0861 detik.

\subsection{Pembahasan}

Pada penelitian ini ditemukan bahwa rocchio classifier dapat membantu permasalahan keluhan pada perusahaan penyedia layanan internet. Berdasarkan hasil implementasi aplikasi ditunjukkan bahwa waktu yang dibutuhkan oleh sistem relatif cepat yaitu kurang dari 1 detik untuk data berjumlah 238 keluhan, dengan menggunakan PHP dan MySQL. Pada penelitian ini dilakukan 8 kali pengujian yang djelaskan pada tabel 1 .

\begin{tabular}{|c|c|c|c|}
\hline No & Proses & Waktu & Keterangan \\
\hline 1 & Preprocessing & 0,911 Detik & $\begin{array}{l}\text { Untuk semua data } \\
\text { training } 238 \text { data } \\
\text { training }\end{array}$ \\
\hline 2 & Cek parsing & 0,0132 Detik & $\begin{array}{l}\text { Ditemukan } 10 \text { token } \\
\text { untuk data ke-238 } \\
\text { sesuai dengan data } \\
\text { sebenarnya, kata } \\
\text { adalah kata penting } \\
\text { dalam keluhan }\end{array}$ \\
\hline 3 & $\begin{array}{l}\text { Percobaan } 1 \\
\text { Parsing } \\
\text { Klasifikasi } \\
\text { Total }\end{array}$ & $\begin{array}{l}\text { 0,0797 Detik } \\
\text { 0,1994 Detik } \\
\text { 0,2791 Detik }\end{array}$ & $\begin{array}{l}\text { Peringkat } 2=0,295 \\
\text { Peringkat } 3=0,1042 \\
\text { Peringkat } 1=0,0861\end{array}$ \\
\hline 4 & $\begin{array}{l}\text { Percobaan } 2 \\
\text { Parsing } \\
\text { Klasifikasi } \\
\text { Total }\end{array}$ & $\begin{array}{l}\text { 0,0182 Detik } \\
\text { 0,0706 Detik } \\
\text { 0,0892 Detik }\end{array}$ & $\begin{array}{l}\text { Peringkat } 2=0,410 \\
\text { Peringkat } 3=0,2921 \\
\text { Peringkat } 1=0,1930\end{array}$ \\
\hline 5 & $\begin{array}{l}\text { Percobaan } 3 \\
\text { Parsing } \\
\text { Klasifikasi } \\
\text { Total }\end{array}$ & $\begin{array}{l}\text { 0,0769 Detik } \\
0,0846 \text { Detik } \\
0,1616 \text { Detik }\end{array}$ & $\begin{array}{l}\text { Peringkat } 2=0,503 \\
\text { Peringkat } 3=0,3429 \\
\text { Peringkat } 1=0,2189\end{array}$ \\
\hline 6 & $\begin{array}{l}\text { Percobaan } 4 \\
\text { Parsing } \\
\text { Klasifikasi } \\
\text { Total }\end{array}$ & $\begin{array}{l}\text { 0,0155 Detik } \\
0,0771 \text { Detik } \\
\text { 0,0925 Detik }\end{array}$ & $\begin{array}{l}\text { Peringkat } 2=0,4898 \\
\text { Peringkat } 3=0,4680 \\
\text { Peringkat } 1=0,2240\end{array}$ \\
\hline 7 & $\begin{array}{l}\text { Percobaan } 5 \\
\text { Parsing } \\
\text { Klasifikasi } \\
\text { Total }\end{array}$ & $\begin{array}{l}\text { 0,0182 Detik } \\
\text { 0,0765 Detik } \\
\text { 0,0948 Detik }\end{array}$ & $\begin{array}{l}\text { Peringkat } 2=0,5128 \\
\text { Peringkat } 3=0,4307 \\
\text { Peringkat } 1=0,2897\end{array}$ \\
\hline 8 & $\begin{array}{l}\text { Percobaan } 6 \\
\text { Parsing } \\
\text { Klasifikasi } \\
\text { Total } \\
\end{array}$ & $\begin{array}{l}\text { 0,0224 Detik } \\
\text { 0,0734 Detik } \\
\text { 0,0958 Detik }\end{array}$ & $\begin{array}{l}\text { Peringkat } 2=0,5225 \\
\text { Peringkat } 3=0,4361 \\
\text { Peringkat } 1=0,3014\end{array}$ \\
\hline 9 & $\begin{array}{l}\text { Percobaan } 7 \\
\text { Parsing } \\
\text { Klasifikasi } \\
\text { Total } \\
\end{array}$ & $\begin{array}{l}\text { 0,0197 Detik } \\
\text { 0,0714 Detik } \\
\text { 0,0912 Detik }\end{array}$ & $\begin{array}{l}\text { Peringkat } 1=0,4111 \\
\text { Peringkat } 3=0,2756 \\
\text { Peringkat } 2=0,2282\end{array}$ \\
\hline 10 & $\begin{array}{l}\text { Percobaan } 8 \\
\text { Parsing } \\
\text { Klasifikasi } \\
\text { Total }\end{array}$ & $\begin{array}{l}\text { 0,0158 Detik } \\
\text { 0,0717 Detik } \\
\text { 0,0875 Detik }\end{array}$ & $\begin{array}{l}\text { Peringkat } 1=0,4317 \\
\text { Peringkat } 3=0,4283 \\
\text { Peringkat } 2=0,2908\end{array}$ \\
\hline
\end{tabular}

Pada tabel 1 ditunjukkan beberapa kolom yang menunjukkan proses, waktu, dan keterangan. Secara fungsional aplikasi telah berjalan $100 \%$. Pengujian yang dilakukan pada penelitian ini adalah secara presisi dan waktu setiap proses. Pada percobaan yang dilakukan ditemukan bahwa hasil telah sesuai dengan kondisi yang sebenarnya. Khusus percobaan pada data tes maka yang ditunjukkan adalah peringkat terhadap kelompok data training beserta nilai kedekatan. Berdasarkan hasil pengujian yang dilakukan maka diperoleh nilai-rata rata proses 
parsing adalah 0,0333 detik, rata-rata proses klasifikasi adalah 0,0905 detik, dan rata-rata keseluruhan proses adalah 0,1238 detik.

\section{KESIMPULAN}

Berdasarkan penelitian yang dilakukan maka dapat disimpulkan beberapa hal antara lain rocchio classifier dapat membantu klasifikasi keluhan pelanggan sesuai dengan penanganan, jumlah data yang diperoleh sangat mempengaruhi metodologi penelitian dan mempengaruhi komputasi aplikasi. Secara umum waktu yang dibutuhkan untuk melakukan preprocessing, parsing, klasifikasi dan keseluruhan proses tergolong cepat dan dapat menyelesaikan permasalahan. Saran yang dapat diberikan dari penelitian ini adalah menambah jumlah data sehingga dapat diperoleh stopword atau kamus data yang sesuai pada permasalahan di masa yang akan datang.

\section{PUSTAKA}

Aziz, A., Saptono, R. and Suryajaya, K.P., 2016. Implementasi Vector Space Model dalam Pembangkitan Frequently Asked Questions Otomatis dan Solusi yang Relevan untuk Keluhan Pelanggan. Scientific Journal of Informatics, 2(2), pp.111-121.

Brown K, 2015. Global Internet Report 2015, Mobile Evolution And Development Of The Internet. Internet Society. Report: 2015.

Data dan Statistik Kementerian Komunikasi dan Informatika RI, 2013. Perkembangan Jumlah Izin Penyelenggaraan Jasa ISP Tahun 19962012. Kemenkominfo RI.

Fajarita L. Achmad B., 2015. Analisa dan Perancangan Sistem Informasi Penanganan Keluhan Pelanggan Pada PT. Paron Indonesia. Seminar Teknologi Informasi dan Komunikasi. ISSN 2089-9815.

Haryono, H., 2016. ANALISIS PERANCANGAN SISTEM KOMPLAIN PELANGGAN PADA PT. RAYTEL INDONESIA. JREC (Journal of Electrical and Electronics), 3(2).

Khan, A.A., Jamwal, S. and Sepehri, M.M., 2010. Applying data mining to customer churn prediction in an internet service provider. International Journal of Computer Applications, 9(7), pp.8-14.

Lumbanraja, F.R., 2013. Sistem Pencarian Data Teks dengan Menggunakan Metode Klasifikasi Rocchio (Studi Kasus: Dokumen Teks Skripsi). Prosiding SEMIRATA 2013, 1(1).

Marius, P. and Pinotaan, F., 2014. Penggunaan Internet Sektor Bisnis 2013. Asosiasi Penyelenggara Jasa Internet Indonesia. APJII.

Poushter, J., 2016. Smartphone ownership and internet usage continues to climb in emerging economies. Pew Research Center, 22, pp.1-44.

Sanou, B., 2015. ICT facts and figures. The world in, pp.1865-2015.
Suharso, W., 2016, November. PENYELARASAN TUJUAN TI DAN TUJUAN BISNIS PADA PERUSAHAAN LAYANAN INTERNET. In Prosiding SENTRA (Seminar Teknologi dan Rekayasa) (No. 2).

Suharso, W. and Djunaidy, A., 2013. Analisis Customer Churn Menggunakan Bayesian Belief Network (Studi Kasus: Perusahaan Layanan Internet). SISFO Vol 4 No 5, 4.

Tarragó, D.S., Cornelis, C., Bello, R. and Herrera, F., 2014. A multi-instance learning wrapper based on the Rocchio classifier for web index recommendation. Knowledge-Based Systems, 59, pp.173-181.

Yugianus, P., Dachlan, H.S. and Hasanah, R.N., 2013. Pengembangan Sistem Penelusuran Katalog Perpustakaan Dengan Metode Rocchio Relevance Feedback. Jurnal EECCIS, 7(1), pp.47-52. 